
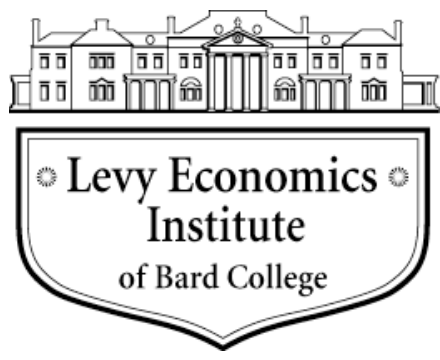

Working Paper No. 872

\title{
Federalism, Fiscal Space, and Public Investment Spending: Do Fiscal Rules Impose Hard Budget Constraints?*
}

by

\author{
Pinaki Chakraborty \\ Levy Economics Institute of Bard College
}

August 2016

\begin{abstract}
* Paper presented at the workshop "Central Local Government Relations: Fiscal Sustainability," organized by the ADB Institute (ADBI), Tokyo, Japan, and Zhongnan University of Economics and Law, Wuhan, China, and held at Zhongnan Univerisity on October 24-25, 2015. The author is grateful to ADBI for the opportunity to write this paper for the workshop. Comments received from Naoyuki Yoshino, Jorge Martinez-Vazquez, Peter Morgan, and Fang Ying are gratefully acknowledged. The author is also grateful to Abhishek for research assistance and to Antra Bhatt for helping with the review of literature. Lekha Chakraborty also made very useful suggestions for improving the draft, and Usha Mathur provided able secretarial assistance. Contact: pinaki.chakraborty@nipfp.org.in.
\end{abstract}

The Levy Economics Institute Working Paper Collection presents research in progress by Levy Institute scholars and conference participants. The purpose of the series is to disseminate ideas to and elicit comments from academics and professionals.

Levy Economics Institute of Bard College, founded in 1986, is a nonprofit, nonpartisan, independently funded research organization devoted to public service. Through scholarship and economic research it generates viable, effective public policy responses to important economic problems that profoundly affect the quality of life in the United States and abroad.

Levy Economics Institute

$$
\text { P.O. Box } 5000
$$

Annandale-on-Hudson, NY 12504-5000

http://www.levyinstitute.org

Copyright (C) Levy Economics Institute 2016 All rights reserved

ISSN 1547-366X 


\begin{abstract}
The primary objective of rule-based fiscal legislation at the subnational level in India is to achieve debt sustainability by placing a ceiling on borrowing and the use of borrowed resources for public capital investment by phasing out deficits in the budget revenue account. This paper examines whether the application of fiscal rules has contributed to an increase in fiscal space for public capital investment spending in major Indian states. Our analysis shows that, controlling for other factors, there is a negative relationship between fiscal rules and public capital investment spending at the state level under the rule-based fiscal regime.
\end{abstract}

Keywords: Fiscal Deficit; Revenue Deficit; Fiscal Rule

JEL Classifications: H00, H6 
India is a federal country of 29 states and 7 centrally administered union territories. It has a highly decentralized federal fiscal structure in which state governments spend more than 56 percent of total public spending but their share of combined revenue is only 38 percent. Although there are multiple channels of transfers, this gap between revenues and expenditures is met primarily through vertical transfers from the Union to the states through the statutory Finance Commission. ${ }^{1}$ Burgeoning fiscal deficits at the subnational level were a major fiscal management issue for India during the 1990s and early 2000s. During this period, piecemeal attempts were made to bring fiscal discipline to the state level, both at the insistence of the central government and in the form of state-specific interventions by multilateral institutions (e.g., the Asian Development Bank and the World Bank).

In order to ensure fiscal discipline, the 12th Finance Commission of India (Finance Commission 2004) recommended rule-based fiscal controls at the state level. This also created a mechanism for providing performance incentive-based transfers for better fiscal management. ${ }^{2}$ Performance incentives in the form of debt consolidation and relief were linked to reductions in state-level fiscal and revenue deficits ${ }^{3}$ relative to the gross state domestic product (GSDP) within a rule-based fiscal framework. ${ }^{4}$ This process of legislative control over deficits was further reinforced by the 13th Finance Commission (Finance Commission 2009) by providing separate performance incentive grants.

As per the recommendations of the 12th Finance Commission, if a state enacted a Fiscal Responsibility Act (FRA) specifying 3 percent of GSDP as the upper bound for its fiscal deficit and eliminated its deficit in the current account of the budget (i.e., revenue deficit) within a specific time period (by 2008-09), the state became eligible for debt rescheduling. If a particular state adhered to those targets specified in the act, a part of the state's debt to the

\footnotetext{
${ }^{1}$ The Finance Commission is a statutory constitutional body appointed by the President of India quinquennially for the distribution of the net proceeds of taxes of the Union government between the Union and the states and establishing principles that should govern the grants in aid of the revenues of the states out of the Consolidated Fund of India. Apart from the Finance Commission, resources to the states are transferred through Planning Commission and various ministries of the Union government. Finance Commission-recommended transfer continues to be the primary channel of resource transfer to the states.

${ }^{2}$ Prior to the recommendations of the Finance Commission in 2004, a few states introduced FRAs on their own. A few of them did it as a part of the subnational structural adjustment lending program support provided by the Asian Development Bank and the World Bank. A review is available in Rao and Chakraborty (2006).

${ }^{3}$ Revenue deficit is the difference between revenue receipts and revenue expenditure and fiscal deficit is the total borrowing or the aggregate resource gap in the budget.

${ }^{4}$ Although state-specific FRAs have other commitments (such as reduction in guarantees given by the state governments, the level of contingent liabilities, and in some cases, level of debt), the incentive-based transfers from the Union government structured by the Finance Commission were linked to the reduction in revenue and fiscal deficits. Thus we primarily focus on these two indicators.
} 
federal government would be written off. All the states in India now have adopted FRAs. The provisions included in these acts are more or less similar across states, particularly with regard to revenue and fiscal deficit reduction. As specified in the state-specific acts, states cannot borrow more than 3 percent of GSDP and are required to eliminate their revenue deficit within a specified time frame. Since the primary objective of the act is to phase out revenue deficits and to put an overall cap on borrowing, the core emphasis therefore is to improve public capital investment. Thus, if revenue deficit is zero, public capital investment will be equal to government borrowing. If there is revenue surplus, investment will be equal to borrowing plus the revenue surplus. The fixed borrowing limit of 3 percent of GSDP on the other hand is to ensure overall fiscal sustainability of subnational debt through a hard budget constraint. State-specific acts also imposed limits on government guarantees, associated contingent liabilities, and off-budget borrowing.

The main objective of this paper is to examine whether the application of a fiscal rule resulted in an increase in the fiscal space for public capital investment spending in Indian states. The focus is state-level capital spending, reflected in state budgets, although it does not include all public sector investment in a state, as data are not readily available. For aggregate public sector investment in a state, there are measurement issues regarding intra-public sector transactions and investments. It is therefore difficult to arrive at a precise estimate and these transactions are not considered in the present analysis.

Although macroeconomic stabilization is a federal government function, subnational deficit controls have implications for both macrostabilization and overall fiscal management in India, since the central government and the states are co-equal partners in public spending and both the levels of governments have large fiscal imbalances. In other words, fiscal and macroeconomic stability in a large federation like India depends not only on the fiscal deficit of the central government but also on the states' deficits. In India, states in the pre-FRA period had a combined fiscal deficit almost equal to that of the federal government. The average state fiscal deficit was 4.5 percent of GDP during 1998-99 to 2003-04, while the central government's fiscal deficit was 5.2 percent of GDP for the same period. Since the combined state deficits are large, and given the multilevel fiscal structure, overall deficit reduction may not be fully achieved if deficits are not controlled for by each level of government. From this standpoint, this research paper adds value to understanding the complexities of macro fiscal policies in a large federal system. 


\section{FISCAL RULES: ARE THEY USEFUL?}

Rules may be necessary to restrain governments that engage in discretionary policies which have a deficit bias (Buchanan and Wagner 1977), and to promote consistency in policy commitments (Kydland and Prescott 1977). Koptis (2001) argued for a well-designed rulebased fiscal policy for mitigating a country’s susceptibility to a crisis. According to Koptis, an inconsistency between a country's fiscal stance and its exchange rate regime played an important role in the currency crises of many countries (e.g., Russia, Brazil, and Ecuador). These crises were also due to capital outflows where foreign investors' perceptions about government solvency were an important factor. Khemani (2008) argued that in decentralized economies, the implementation of fiscal rules could be useful for incentivizing better fiscal performance by state and local governments, and thus promoting fiscal prudence. However, the incentive structure may need to be designed in such a way that local governments do not circumvent transfer conditionalities, and in doing so not follow fiscal rules. The extant empirical literature, such as Krogstrup and Walti (2008), Feld and Kirchgssner (2006), and Schaltegger (2001), shows that fiscal rules have a significant impact on budget balances. A few studies carried out using US data show that the strength of the fiscal rule was directly proportional to a reduction in unexpected deficits (Poterba 1995; Alt and Lowry 1994; Alesina and Bayoumi 1996). In the case of Canadian provinces, a few studies indicate that provincial legislation to limit deficits led to stronger budget balances, ceteris paribus (Tellier and Imbeau 2004). The literature on the impact of fiscal rules on fiscal performance in emerging-market economics is rather scanty (Chakraborty and Dash 2013).

\section{WHY FISCAL RULES MAY NOT WORK}

Milesi-Ferreti (2004) analyzed the effectiveness of fiscal rules in light of "creative accounting.” Creative accounting is defined as a measure by means of which an improvement in the fiscal balance is observed without an accompanying actual improvement in the intertemporal budgetary position of the government. Using a two-period model developed by Hagen and Harden (1996) and assuming that fiscal rules are being imposed on the "measured” fiscal balance and that a penalty must be paid if creative accounting is detected, it is observed that budget transparency is inversely proportional to creative accounting. Additionally, even if the costs of engaging in creative accounting are large, tighter rules may 
still induce creative accounting. Manasse (2007) discussed the incentive effects of budget limits. According to this study, when limits are imposed on the deficit-output ratio, governments keep the deficit just below the limit to avoid sanctions and have no incentive to practice fiscal consolidation during "good times.” These rules then also indirectly have large negative effects on welfare.

Apart from rule-based fiscal controls, there have been wide-ranging international experiences with structural adjustment lending for fiscal consolidation with mixed outcomes. A World Bank (1992) review ${ }^{5}$ observed that adjustment lending was associated with fiscal deficit reduction and an increase in revenue, but the general spending cuts were often at the expense of critically important operation and maintenance and there was too much spending on salaries relative to non-salary inputs. Mavrotas and Quattara (2003), while analyzing the effect of development assistance on public sector behavior, observed that official development assistance (as measured by the OECD) reduced revenues in the short run but raised them in the long run. The study by Gupta et al. (2003) of foreign aid in 107 countries during the period 1970 to 2000 observed that while concessional loans were associated with higher domestic revenue, mobilization grants had the opposite effect.

\section{APPROPRIATE STRUCTURE FOR FISCAL RULES}

The key goal of a fiscal rule is to achieve higher credibility for fiscal policy by reducing discretionary intervention in the conduct of macroeconomic policies. With regard to design, a fiscal rule should be well defined, transparent, focused, consistent with macroeconomic policies, simple, flexible enough to accommodate cyclical fluctuations, enforceable, and supported by efficient policies (Kopits and Symansky 1998). It has been argued that a fiscal rule indicator needs to be operationally simple, flexible, growth oriented, and easily monitored.

In the case of decentralized economies, two approaches are generally adopted: an autonomous approach and a coordinated approach. In the case of a coordinated approach, all subnational governments are subject to the same rule. In the case of India, the fiscal rule as

\footnotetext{
${ }^{5}$ Cited in World Bank (2005)
} 
imposed is also simple and has been applied with uniform deficit reduction targets across states. The European Union and emerging economies focused on targets that are numerical and uniform across countries (the autonomous approach).

A key component of the design of fiscal rules is ensuring their sustainability and deciding on an optimal level of fiscal rule indicators. The literature on sustainable fiscal rules has evolved since the 1990s, when rules were considered to be appropriate if they respected the intertemporal budget constraint. Spaventa (1987) finds that a design where the sustainability of a fiscal rule is based on the satisfaction of the budget constraint does not take into account the financial situation of the public sector. Using a sovereign debt framework (which assumes that the government cannot choose the duration of its debt), Hatchondo, Martinez, and Roch (2012) show that implementing a debt ceiling may prove beneficial for the government, as an expectation of a lower debt level would lead to a decline in interest rates. They also find that lower debt ceilings lead to less responsiveness in the interest rate to income shocks, and consumption becomes less volatile as fiscal policy becomes less procyclical. Pappa and Vassilatos (2007) and Poplawski Ribeiro, Beetsma, and Schabert (2008) find that debt ceilings may be better indicators than a ceiling on the government's deficit.

A more recent framework by Bertelsmann (2013) supports the establishment of independent fiscal institutions (IFIs) as an important component of ensuring that the fiscal rules are adhered to and that the mechanism includes design factors to ensure strong monitoring and evaluation of rules on a continuous basis. These IFIs could exercise an advisory role, report the true magnitude of government liabilities, and project the long-term implications of fiscal policy and new fiscal policy announcements. Arguments in favor of IFIs include the following: better transparency in public finances; at a more sophisticated level, an IFI can also undertake the task of monitoring and ensuring compliance with a fiscal rule, as well as include sanctions for nonobservance of a debt ceiling; and finally, IFIs can also encourage and assist governments with publishing public finance data at regular intervals and placing these data in the public domain. 


\section{SUBNATIONAL FISCAL RULES IN INDIA}

In India, at the instance of the World Bank and the Asian Development Bank, fiscal rules were introduced by a few states prior to the recommendations of the 12th Finance Commission. This was done through multilateral structural adjustment lending to the states by these banks (Rao and Chakraborty 2007). The 12th Finance Commission’s recommendations became operational in fiscal year 2005-06. The states that enacted FRAs prior to this and in accordance with the recommendation of the 12th Finance Commission are shown in appendix table A2. ${ }^{6}$ The incentive structure of the FRA proposed by the 12th Finance Commission is the following:

[E]ach state should enact fiscal responsibility legislation. This has been stipulated as a precondition for availing the debtrelief scheme. This legislation should, at a minimum, provide for (a) eliminating revenue deficit by 2008-09; (b) reducing fiscal deficit to 3 percent of GSDP or its equivalent defined as ratio of interest payment to revenue receipts; (c) bringing out annual reduction targets of revenue and fiscal deficits; (d) bringing out annual statement giving prospects for the state economy and related fiscal strategy; (e) bringing out special statements along with the budget giving in detail number of employees in government, public sector, and aided institutions and related salaries.

To avail themselves of the debt consolidation and relief facility under the act, all the states (except Sikkim and West Bengal) enacted their FRAs with a uniform deficit target (both revenue and fiscal deficits) following the submission of 12th Finance Commission report in 2004. Already existing state-specific FRAs were amended to comply with the recommendations of the 12th Finance Commission. It is important to highlight that the 12th Finance Commission emphasized that all states only needed to enact an FRA as prescribed to receive debt consolidation. However, to be eligible for debt relief, states were required to adhere to the targets of deficit reduction prescribed in the act. In addition to adhering to the Commission's prescription of numerical deficit targets, several states volunteered to impose different fiscal restrictions on themselves, such as targeting outstanding liabilities, institutional rules for expenditure management, and timely review of fiscal performance, as summarized in Simone and Topalova (2009). The process of fiscal consolidation continued

\footnotetext{
${ }^{6}$ The 12th Finance Commission's report was submitted in November 2004 and the recommendations became operational beginning in the fiscal year 2005-06.
} 
for the period from fiscal years 2005-06 to 2009-10, the five-year award period of the 12th Finance Commission. ${ }^{7}$ The 13th Finance Commission also proposed an incentive framework to ensure that the states remain within the FRA deficit targets. There was some apprehension that maintaining fiscal prudence post-global financial crisis would be a challenging task.

As articulated in 13th Finance Commission Report, in 2009-10 the combined (Union and the states) debt-to-GDP ratio remained high (82 percent) despite fiscal correction through the implementation of fiscal responsibility frameworks during the period from 2005 to 2010 . The 13th Finance Commission proposed a target of 68 percent for the combined Union and state debt-to-GDP ratio by the year 2014-15, with the central government's debt-to-GDP ratio reaching 45 percent. The Commission had taken the elimination of the revenue deficit as the long-term and permanent target for both the Union and the states. The Commission's prescribed fiscal consolidation path for the central government required a decline in the revenue deficit from 4.8 percent of GDP (as projected for the fiscal year 2009-10) to a revenue surplus of 0.5 percent of GDP by 2014-15. These prescriptions of fiscal consolidation in turn allowed for acceleration in capital expenditures to 3.5 percent of GDP by 2014-15. As assessed by the 13th Finance Commission, the proposed fiscal consolidation path was growth promoting, as it focused on the elimination of the revenue deficit to ensure that net public borrowing was exclusively used for growth-enhancing public investment. ${ }^{8}$

As noted in the 13th Finance Commission Report, 26 states (operating under their FRA) reached their expenditure and debt targets ahead of the scheduled timeframe proposed by the 12th Finance Commission and showed significant fiscal correction. According to the 13th Finance Commission, the main reason behind this fiscal correction was the benefit of higher shares of federal taxes due to the high federal tax growth and improvement in state tax revenues. State debt-to-GSDP was also reduced sharply during this period to below 30 percent of GDP. However, there were wide variations in fiscal performance among the states (an issue we discuss later). In order to continue to strengthen the process of fiscal

\footnotetext{
${ }^{7}$ As per the Indian Constitution, the Finance Commission is a temporary body appointed quinquennially to recommend devolution of taxes and grants to the states for five years.

${ }^{8}$ The Commission recognized that states were permitted to borrow more than the Fiscal Responsibility and Budget Management Act (FRBMA) targets in 2008-09 and 2009-10. This specific relaxation of targets for two years was a part of the fiscal stimulus package announced by the central government to increase government spending to contain the adverse impact of the global financial crisis. Due to this relaxation of target, the Commission allowed one year (i.e., 2010-11) as a year of adjustment and recommended fiscal consolidation from 2011-12 (Finance Commission 2009: 25).
} 
consolidation at the state level, the 13th Finance Commission made the following recommendations:

The Medium Term Fiscal Plan should make explicit the values of the parameters underlying expenditure and revenue projections and the band within which these parameters can vary while remaining consistent with FRBMA targets.

The FRBMA should specify the nature of shocks which would be required before any relaxation of FRBMA targets.

States should amend/enact their FRBMAs to build in the fiscal reform adopted by the state. State-specific grants recommended for a state should be released upon compliance with fiscal reform goals. (Finance Commission 2010: 6)

\section{KEY FISCAL INDICATORS: THE LONG-RUN TREND}

In 1991, a large combined fiscal deficit on the order of 9.9 percent of GDP (i.e., the Union's fiscal deficit of 6.6 percent and combined state deficit of 3.19 percent) and a huge external current account deficit, coupled with dwindling foreign exchange reserves, are considered to be the factors that contributed to the macroeconomic crisis and the subsequent economic reforms in India. One key component of the big-bang economic reform was fiscal consolidation. Fiscal reform was a combination of tax reforms, expenditure control, and reforms in the management of public debt. We will discuss these very briefly.

As part of the fiscal reform, a major tax reform initiative was undertaken to overhaul the country's complex tax system. Simplification and moderation in the tax rate and modernization of the tax administration system were the main components of tax reform. The peak rate of personal income tax was reduced from 50 percent in 1991 to 30 percent in 199798. ${ }^{9}$ The reform of indirect taxes was comprised of a reduction in the customs tariffs and the Union excise duty structure. A sharp rate reduction in indirect taxes contributed to the decline in indirect tax revenue during the 1990s, but direct tax revenue had shown commendable growth during this period. As the share of indirect taxes was much higher than direct taxes, the increase in the direct tax could not offset the revenue loss from indirect taxes.

\footnotetext{
${ }^{9}$ Currently India has one of the lowest income tax rates in the world.
} 
As revenues were not rising, in the initial years of economic reform fiscal consolidation was achieved by reducing discretionary development spending through reducing capital expenditure for public investment. However, the success achieved in containing the deficit during first half of 1990s was short lived. The impact of the Fifth Pay Commission award ${ }^{10}$ created an explosive fiscal imbalance at the federal level, as well as in the states, taking the combined fiscal deficit to 9.39 percent of GDP in 1999-2000 (see figure 1). However, the fiscal deficit started declining gradually from 2002-03 and reached an all-time low of 4 percent in 2007-08. This was a spectacular improvement in the fiscal situation of all levels of government compared to 1991. This phase was also characterized by high growth in revenues. During 2003-04 to 2007-08, central government revenues grew at the rate of 18.58 percent, and the states' revenues grew at the rate of 16.46 percent. GDP growth during the same period was 8.89 percent per annum.

In 2003, the central government enacted the Fiscal Responsibility and Budget Management Act (FRBMA). As mentioned earlier, the states also enacted their state-level Fiscal Responsibility Acts (FRAs) on the recommendation of the 12th Finance Commission. All of the states, except West Bengal and Sikkim, enacted their respective FRAs during this period. Many public finance specialists attributed the decline in deficits in the years leading up to 2007-08 to FRA legislation. However, with the global financial crisis, India again experienced high levels of fiscal imbalance (see figure 1), especially at the level of the central government. The changes in the fiscal deficit as a percentage of GDP for the period from 1990-91 to 2014-15 (budget estimates) is given in figure 1. However, states remained fiscally prudent during the post-global financial crisis period. The outstanding-debt-to-GDP ratio also declined significantly in recent years and fell well below the targeted level recommended by the 13th Finance Commission, both for the central and state governments.

\footnotetext{
${ }^{10}$ The Fifth Pay Commission award was a pay hike for the government employees, representing a consequent increase in government expenditure.
} 


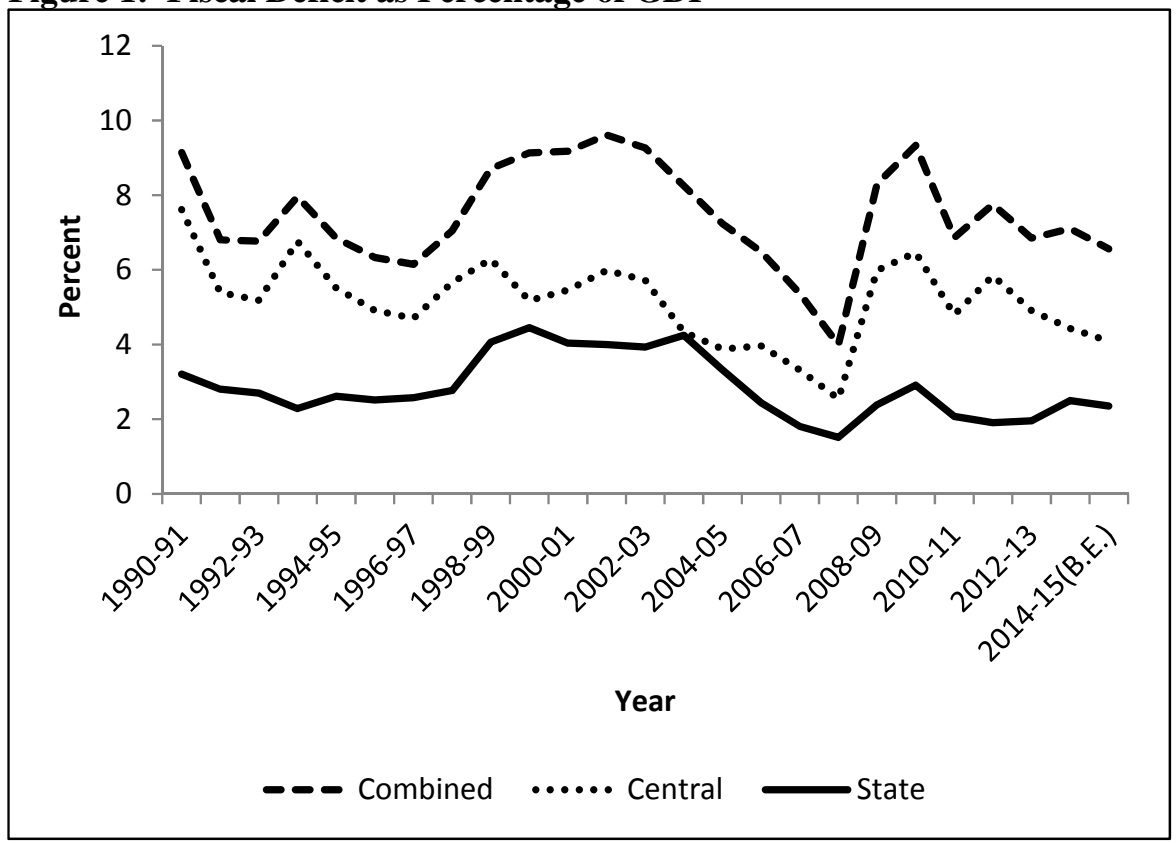

Figure 2: Outstanding Debt as Percentage of GDP

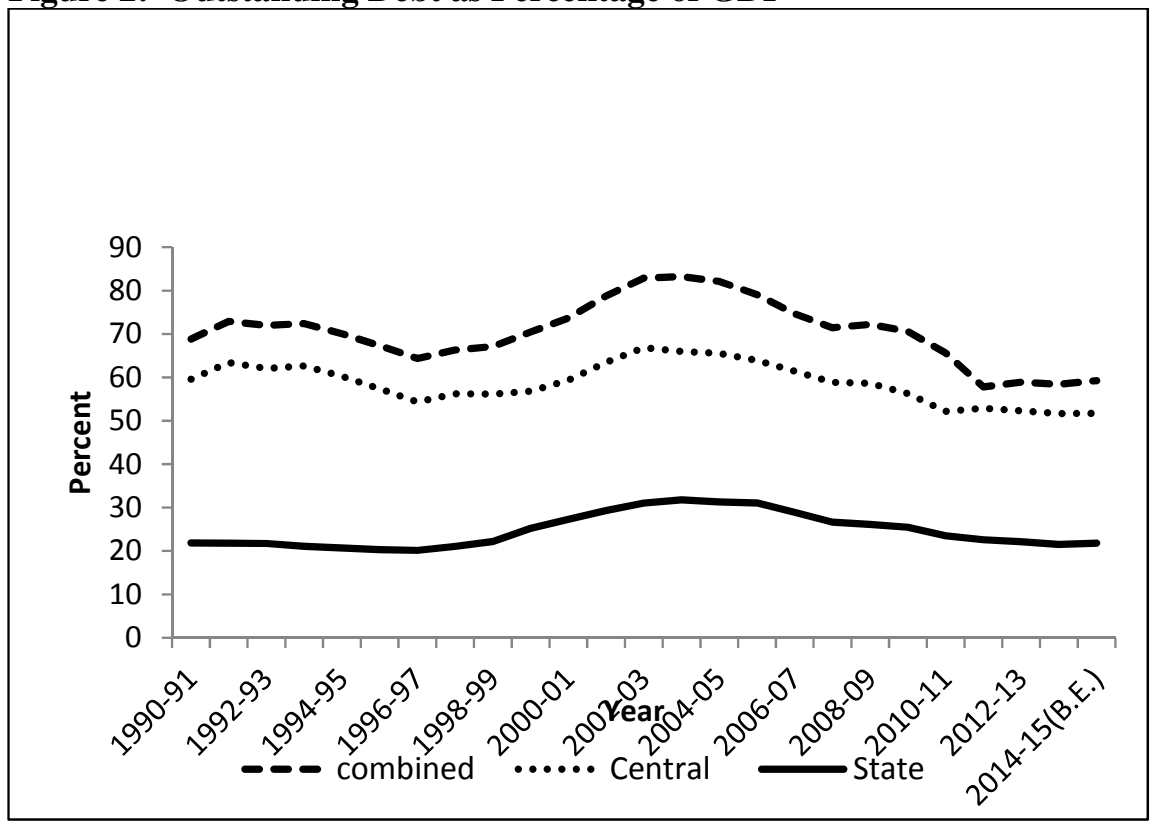

Although key indicators of fiscal prudence (viz., deficit and debt as a percentage of GDP) declined for the states over the years, it is important to examine the expenditure profile of the central government and states. As evident from figure 3, the aggregate expenditure-to-GDP ratio (all states) declined gradually until 2011-12 and started increasing in 2012-13. If we 
consider capital expenditure alone, it is evident that there has been a decline in the Union's capital-expenditure-to-GDP ratio from 2003-04. However, since 2002-03 the capital expenditure of the states in relation to GDP is higher compared to the central government (see figures 3 and 4). In other words, post-FRA, state governments have become the primary drivers of capital spending, both for the social and economic sector, while the central government's capital-expenditure-to-GDP ratio continued to decline during this period. It needs to be highlighted that in the pre-FRA period, the central government was the primary driver of capital spending, but this is no longer true. This shift in capital spending at the state level is an important development and one needs to examine how this shift plays out in the medium term in terms of the composition and quality of public investment spending.

Figure 3: Total Expenditure as a Percentage of GDP

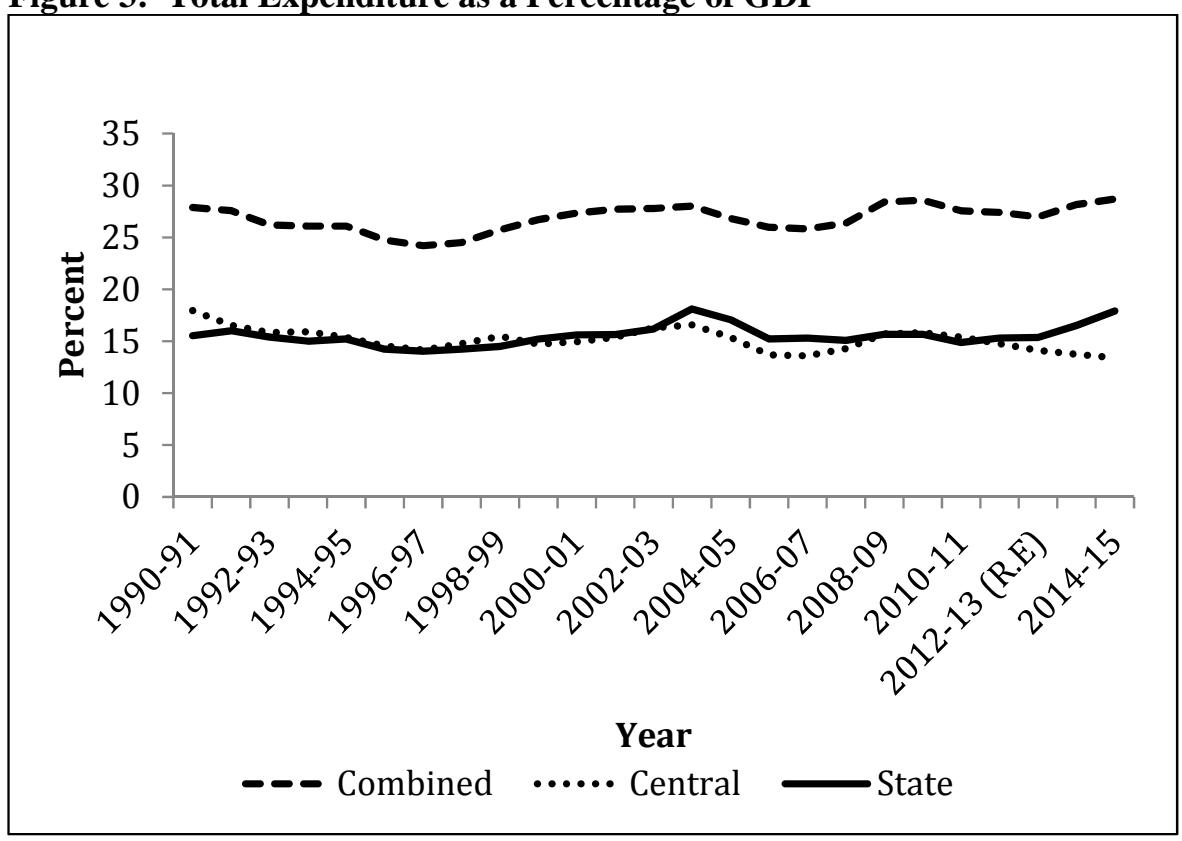




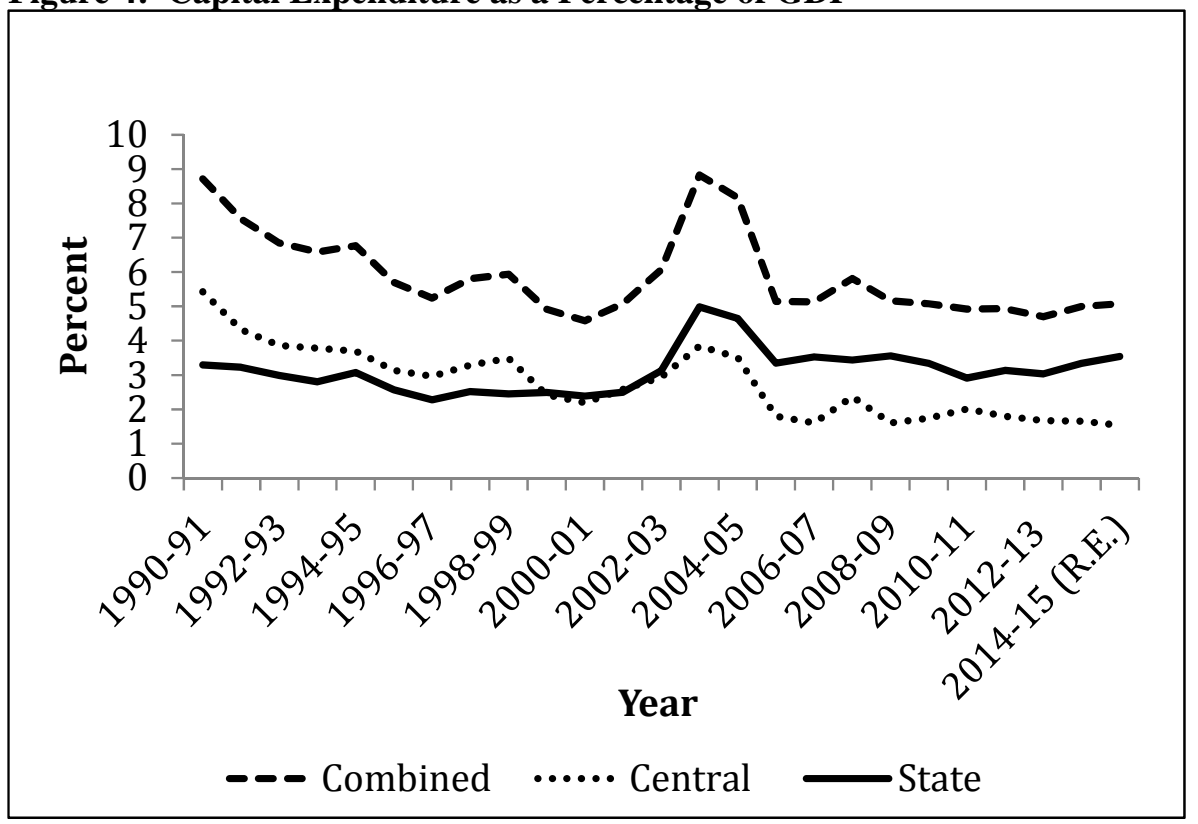

Our analysis shows that the era of rule-based fiscal control witnessed a sharp reduction in the overall fiscal imbalance at the state level. This improvement in fiscal health can be characterized as an intertemporal reduction in both the fiscal- and revenue-deficits-to-GDP ratios. As they evolved up to 2007-08, the fiscal positions of the state generated a revenue surplus and brought down the gross fiscal-deficit-to-GDP ratio below the 3 percent FRA target. This also implies that states have overadjusted their fiscal deficits. At the state level, fiscal consolidation has been achieved through: higher state tax revenue mobilization, largely due to introduction of a value added tax (VAT) at the state level in 2005; increased central devolution due to the growth in federal taxes; and a reduction in the revenue- and expenditure-to- GSDP ratios, primarily due to the decline in economic and social services expenditures and interest burden. ${ }^{11}$ It is argued that improved fiscal balances have also contributed to the increase in fiscal space at the state level. Although, in the post-global financial crisis years there was fiscal expansion at the central government level, resulting in a sharp increase in the fiscal deficit of the central government, the states continued with fiscal restraints and in the aggregate state fiscal deficits remained below the FRA target between 2008-09 and 2014-15 (budget estimates). However, differences were observed in the interstate fiscal imbalance profile. Though the rate of increase of deficits varied across states,

\footnotetext{
${ }^{11}$ It is observed that the decline in the interest burden in the last couple of years is due to the softening of interest rates on government securities. It is also argued that measures, such as debt swap schemes in a lowinterest regime, have benefited the states in reducing the interest burden.
} 
most of the states were able to generate revenue surpluses and successfully reduced their fiscal deficits below 3 percent of GSDP during the post-FRA period. It needs to be emphasized that the states that achieved a revenue surplus and a fiscal deficit level below 3 percent of GSDP were also the ones that had a reasonably better history of fiscal management and fiscal prudence (table 1). A comparison of the fiscal imbalance profile ex ante-FRA and ex post-FRA is given in figures 5.1 to 5.9. In these figures states are categorized as high-, middle-, and low-income states. Fiscal imbalance profiles for special category states are shown in figures 5.10, 5.11, and 5.12. ${ }^{12}$ As is evident, most states overadjusted their fiscal deficits. Our data analysis also suggests that low-income states have adjusted their deficits more compared to high- and middle-income states. In other words, these states have borrowed less than the prescribed limit of borrowing under the FRAs, with exceptions in a few states (e.g., Kerala, Punjab, and West Bengal). These three states had to borrow to finance the deficits in their revenue accounts.

\footnotetext{
${ }^{12}$ Special category states are the states in north east India and other hilly states in the northern part of India with special federal fund dispensation due to their higher fiscal and cost disabilities.
} 
Table 1: Major Fiscal Indicators (as a percent of GSDP)

\begin{tabular}{|c|c|c|c|c|c|c|}
\hline & \multicolumn{2}{|c|}{ Revenue Deficit } & \multicolumn{2}{|c|}{ Fiscal Deficit } & \multicolumn{2}{|c|}{ Primary Deficit } \\
\hline & $\begin{array}{c}\text { Average } \\
\text { before } \\
\text { FRBM } \\
\end{array}$ & $\begin{array}{c}\text { Average } \\
\text { after } \\
\text { FRBM } \\
\end{array}$ & $\begin{array}{l}\text { Average } \\
\text { before } \\
\text { FRBM } \\
\end{array}$ & $\begin{array}{l}\text { Average } \\
\text { after } \\
\text { FRBM } \\
\end{array}$ & $\begin{array}{c}\text { Average } \\
\text { before } \\
\text { FRBM } \\
\end{array}$ & $\begin{array}{c}\text { Average } \\
\text { after } \\
\text { FRBM } \\
\end{array}$ \\
\hline \multicolumn{7}{|c|}{ Group A } \\
\hline Goa & 1.7 & -0.5 & 4.6 & 2.8 & 1.7 & 0.8 \\
\hline Maharashtra & 2.4 & -0.3 & 4.1 & 1.6 & 2.0 & -0.1 \\
\hline Haryana & 1.4 & 0.5 & 3.3 & 2.3 & 0.9 & 0.9 \\
\hline Gujarat & 3.2 & 0.0 & 5.1 & 2.4 & 2.3 & 0.4 \\
\hline Tamil Nadu & 1.7 & -0.2 & 2.8 & 2.0 & 1.0 & 0.4 \\
\hline \multicolumn{7}{|c|}{ Group B } \\
\hline Kerala & 2.7 & 2.2 & 4.2 & 3.4 & 1.7 & 1.0 \\
\hline Punjab & 3.3 & 2.3 & 4.8 & 3.3 & 1.2 & 0.4 \\
\hline Karnataka & 0.9 & -0.8 & 3.1 & 2.5 & 1.4 & 0.8 \\
\hline Andhra Pradesh & 1.6 & -0.4 & 4.1 & 2.4 & 1.3 & 0.5 \\
\hline West Bengal & 4.9 & 2.5 & 5.1 & 3.3 & 1.7 & 0.3 \\
\hline \multicolumn{7}{|c|}{ Group C } \\
\hline Rajasthan & 3.3 & -0.1 & 5.7 & 2.1 & 2.0 & -0.4 \\
\hline Jharkhand & 1.3 & -1 & 6.1 & 2.7 & 4.5 & 0.8 \\
\hline Chhattisgarh & 0.4 & -2.5 & 2.7 & 0.7 & 0.6 & -0.4 \\
\hline Madhya Pradesh & 2.3 & -2.5 & 4.9 & 2.2 & 2.1 & 0.1 \\
\hline Odisha & 3.7 & -2.2 & 6.0 & 0.0 & 1.7 & -1.9 \\
\hline Uttar Pradesh & 3.0 & -0.4 & 5.0 & 3.4 & 1.7 & 0.6 \\
\hline Bihar & 2.1 & -2.6 & 5.6 & 2.2 & 1.2 & -0.1 \\
\hline \multicolumn{7}{|c|}{ Special Category States } \\
\hline Sikkim & -10.1 & -6.2 & 5.0 & 1.3 & 1.5 & -0.7 \\
\hline Uttarakhand & 2.1 & -0.7 & 4.7 & 2.7 & 2.2 & 0.6 \\
\hline Himachal Pradesh & 5.9 & -0.1 & 9.2 & 3.7 & 3.7 & -0.5 \\
\hline Nagaland & -6.1 & -5.3 & 3.6 & 3.6 & 0.0 & 0.5 \\
\hline Tripura & -0.8 & -7.5 & 5.4 & -0.1 & 1.7 & -3.0 \\
\hline Mizoram & 2.9 & -3.3 & 14.5 & 6.4 & 8.3 & 2.0 \\
\hline Meghalaya & -0.5 & -1.6 & 4.3 & 2.7 & 1.8 & 0.9 \\
\hline Arunachal Pradesh & -4.6 & -13.5 & 7.8 & 2.9 & 3.2 & -0.5 \\
\hline Jammu and Kashmir & -3.2 & -5.7 & 4.9 & 5.3 & 0.3 & 1.3 \\
\hline Manipur & 1.8 & -12.1 & 8.3 & 4.8 & 3.6 & 0.8 \\
\hline Assam & 1.4 & -1.8 & 3.2 & 0.6 & 0.6 & -1.3 \\
\hline
\end{tabular}

Note: The timeframe of the state-specific average differs across states, as different states introduced their FRAs at different points in time. For details, see appendix A2.

Note: The “-” sign indicates a surplus.

Source: Reserve Bank of India Study on State Finances 2014-15 
Figure 5.1

High Income States: Revenue Deficit

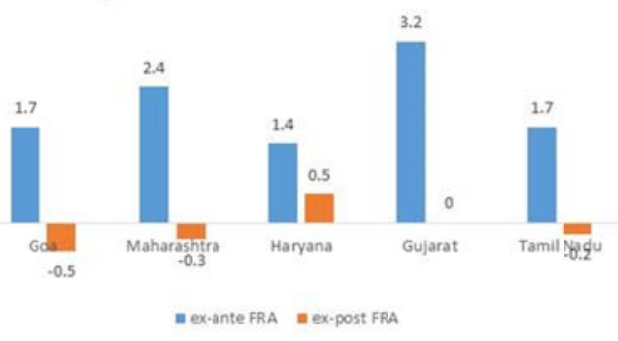

Figure 5.2

High Income States:Fiscal Deficit

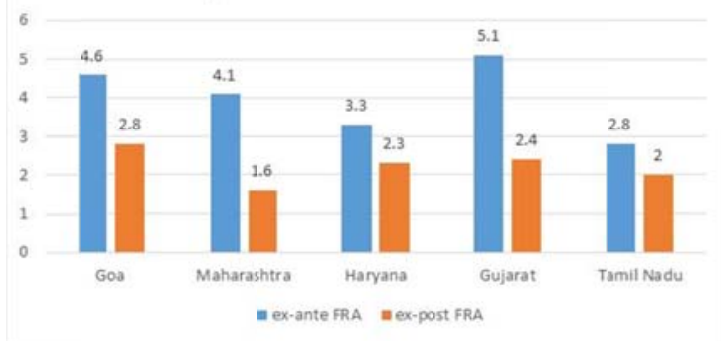

Figure 5.3

High Income States: Primary Deficit

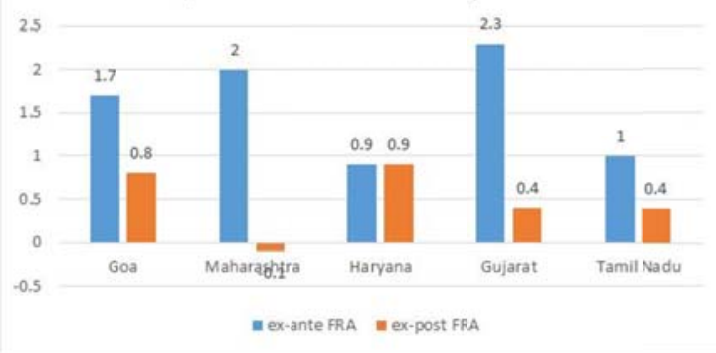

Figure 5.5

Middle Income States: Fiscal Deficits

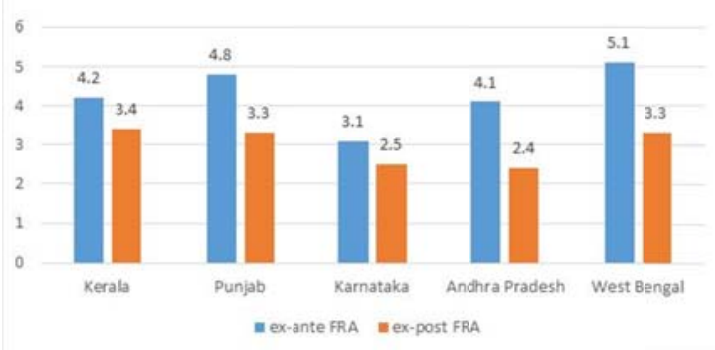

Figure 5.7

Low Income States: Revenue Deficits

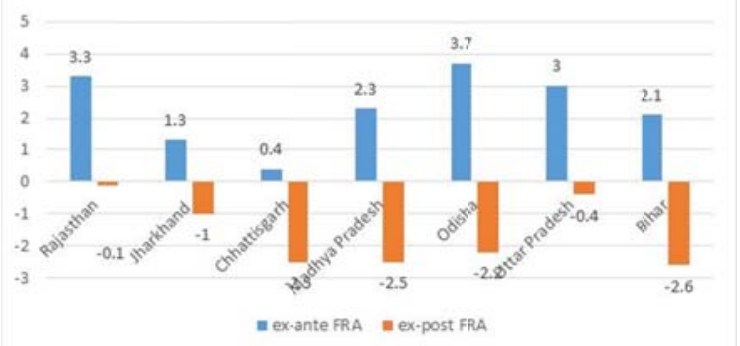

Figure 5.4

Middle Income States: Revenue Deficits

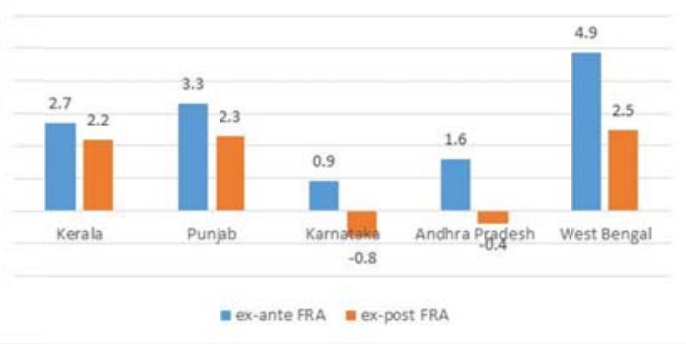

Figure 5.6

Middle Income States: Primary Deficits

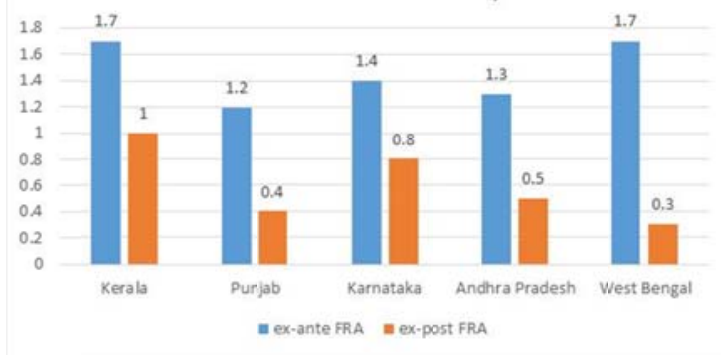


Figure 5.9

Low Income States: Primary Deficits

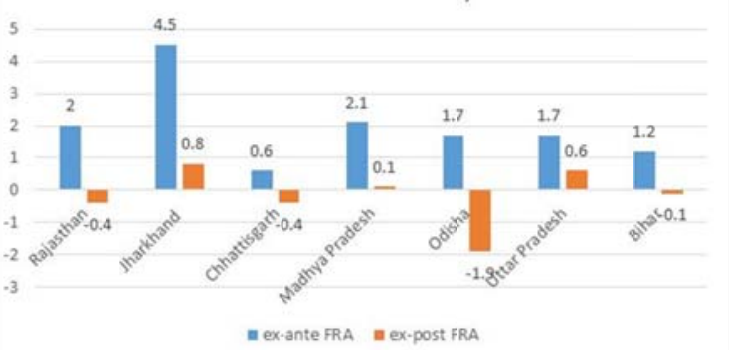

Figure 5.10

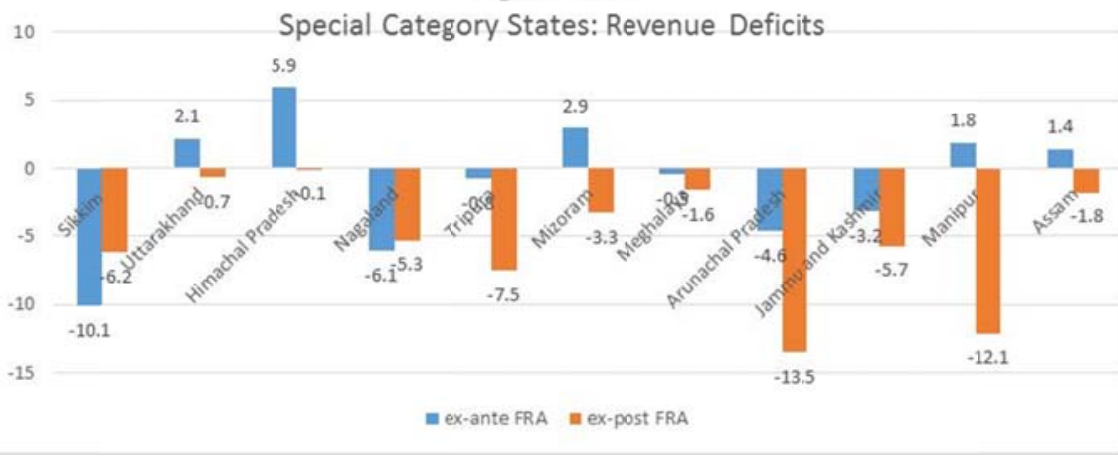

Figure 5.11

Special Category States: Fiscal Deficits

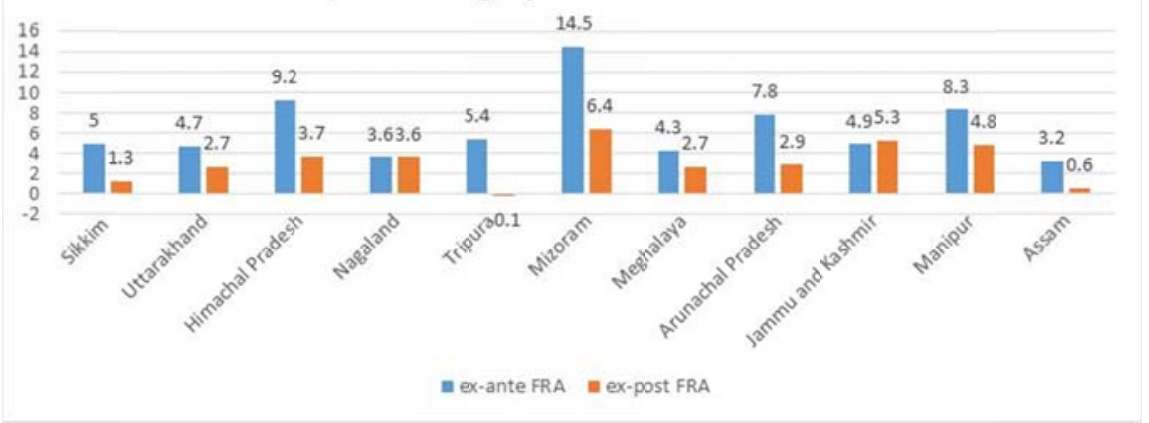

Figure 5.12

Special Category States: Primary Deficits

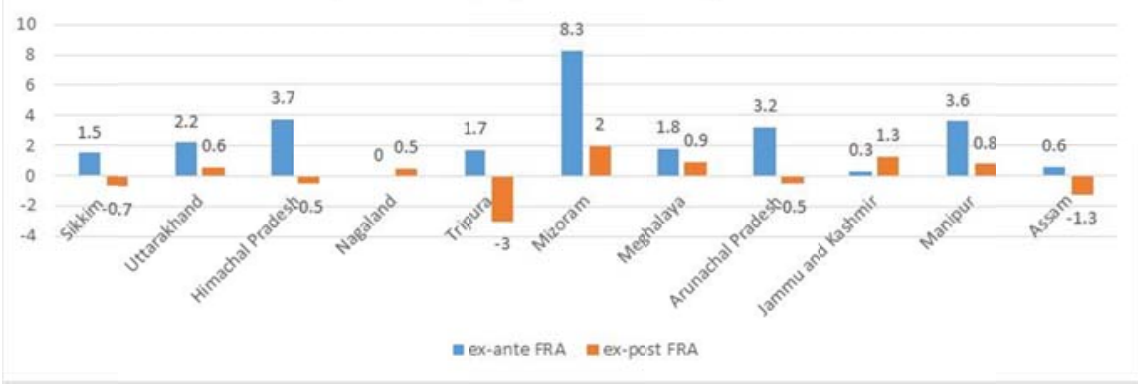


Our state-specific descriptive analysis of fiscal balances also suggests that the overall statelevel fiscal balance has improved with the introduction of a fiscal rule. However, statespecific fiscal imbalances are different across states, especially with regard to revenue deficits. A few states continued to have deficits in their revenue accounts, implying borrowed resources were being used for financing revenue or current expenditure. On the other hand if we consider fiscal deficits, most states remained within the prescribed 3 percent FRA target.

This descriptive analysis does not conclusively establish the exact impact of a fiscal rule on fiscal balances, the way state-level fiscal consolidation has been achieved, or the nature of the relationship between different state-level macro and fiscal variables. One needs to control for such factors to examine the impact of a fiscal rule on fiscal balances and spending. The descriptive analysis also does not help in understanding the process of fiscal adjustment in a rule-based fiscal control regime across states. Due to multiple factors, panel data analysis, which is well suited to the studies that deal with dynamic changes, is used to address these issues. Our analysis used a dataset of 14 major non-special category states ${ }^{13}$ spread over 15 years (from fiscal year 2000-01 to 2014-15) to examine the fiscal rules and public investment spending at the state level. We have used the Arellano Bond Panel estimation. ${ }^{14}$

\section{THE ECONOMETRIC ESTIMATION}

The final model has been defined to include two different determinants (per capita gross state domestic product and per capita central government transfer) and two different dummies (VAT and FRA), with the FRA dummy being the most important variable of interest.

\footnotetext{
${ }^{13}$ These states are Andhra Pradesh, Bihar, Gujarat, Haryana, Karnataka, Kerala, Madhya Pradesh, Maharashtra, Orissa, Punjab, Rajasthan, Tamil Nadu, Uttar Pradesh, and West Bengal. Small and/or special category states are ignored in this study as they are overreliant on assistance from the central government. Overdependence on transfers from the central government severely constrains the fiscal autonomy of such states, and hence, it affects their public finance management ability.

${ }^{14}$ Arellano and Bond (1991) suggested that if one is considering the orthogonality condition that exists between lagged values of the dependent variable and the disturbance variable, then the additional instrument can be obtained in the dynamic panel data model.
} 
Econometrically, the model can be specified as follows:

$$
\begin{gathered}
\mathrm{K}_{\mathrm{i}, \mathrm{t}}=\delta \mathrm{K}_{\mathrm{i}, \mathrm{t}-\mathrm{t}}+\beta_{1} \mathrm{gpc}_{\mathrm{i}, \mathrm{t}}+\beta_{2} \text { igft }_{\mathrm{i}, \mathrm{t}}+\beta_{3} \mathrm{D}_{1} \cdot \mathrm{vat}+\beta_{4} \mathrm{D}_{2} . \text { fra }+\mathrm{u}_{\mathrm{i}, \mathrm{t}} \\
\mathrm{u}_{\mathrm{i}, \mathrm{t}} \sim \operatorname{IID}\left(0, \sigma_{u}^{2}\right)
\end{gathered}
$$

Where: $\quad \mathrm{K}=$ per capita capital outlay

gpc $=$ gross state domestic product in per capita (in nominal terms)

igft = per capita intergovernmental fiscal transfers

$\mathrm{D}_{1} \cdot \mathrm{vat}=0$ : ex ante $\mathrm{VAT}$

$$
=1: \text { ex post VAT }
$$

$\mathrm{D}_{2}$.fra $=0$ : ex ante FRA

$$
=1: \text { ex post FRA }
$$

Table 2: Fiscal Impact on Capital Outlay

\begin{tabular}{ll}
\hline Variable & Per-capita Capital Outlay \\
\hline L.K & $0.526^{* * *}$ \\
& $(5.35)$ \\
Igft & $0.167^{* * *}$ \\
& $(6.58)$ \\
Gpc & $0.00413^{* *}$ \\
& $(2.52)$ \\
D1_VAT & $164.0^{* * *}$ \\
& $(2.64)$ \\
D & $-135.6^{*}$ \\
& $(-1.91)$ \\
Const. & -34.6 \\
\end{tabular}

No of observations $=190$

Wald chi2(5) $=1522.11$

Prob $>$ chi $2=0.000$

Source: Author's computations based on Reserve Bank of India Study on State Finances (various dates). Available at: https://rbi.org.in/scripts/AnnualPublications Note: t-statistics in parentheses

$$
{ }^{*} \mathrm{p}<0.1,{ }^{* *} \mathrm{p}<0.05 \text {, and }{ }^{* * *} \mathrm{p}<0.01
$$


Our analysis shows that the lag of per capita capital outlay, per capita transfer (igft), and per capita gross state domestic product (gpc) have a positive and significant impact on an increase in per capita capital outlay, and the VAT dummy also has a positive and significant effect on per capita capital outlay. However, we observed a negative relationship between the FRA dummy and the capital outlay at the state level.

\section{SPENDING INERTIA}

This result is not surprising. We would like to emphasize that states in the post-FRBMA period are extremely cautious in spending, as reflected in their overcorrection of deficits. This has, in turn, depressed capital spending in the states. This spending inertia has also contributed to a large accumulation of cash surplus holdings by states. The Reserve Bank of India’s “Study on State Finances: 2011-12” observed that:

\footnotetext{
The surplus cash balances of the states stood at Rs. 852 billion as on March 11, 2012. These cash balances get automatically invested in the central government's 14-day intermediate treasury bills as well as in auction treasury bills (ATBs) where states are non-competitive bidders, without any ceilings/ limits. Consequently, there is a spillover of the surplus position of the states to the liquidity position of the Centre. The build-up (and volatility) of the central government's cash surplus, in turn, reflects the unintended absorption of liquidity from the banking system which poses a challenge to the reserve bank's monetary management. ${ }^{15}$
}

The same study also pointed out that in its report submitted in fiscal year 2009-10, the 13th Finance Commission "advised the state governments to first utilize their cash balances before taking recourse to fresh borrowings, to finance their deficits so as to reduce the interest burden.”16 However, in practice, this did not happen.

\footnotetext{
${ }^{15}$ http://rbidocs.rbi.org.in/rdocs/Publications/PDFs/7CHSF300312.pdf

${ }^{16}$ http://rbidocs.rbi.org.in/rdocs/Publications/PDFs/7CHSF300312.pdf
} 


\section{CONCLUSIONS}

Though during the post-FRA period there was a reduction in the fiscal and revenue deficits of the states, our econometric estimates show that capital spending for public investment was negatively related to the FRA dummy. It needs to be highlighted that a one-size-fits-all uniform rule across states came under criticism. Since different states operated at different levels of sustainable deficits, imposing a uniform rule implied constraining capital spending unless large revenue surpluses were generated. Our expenditure model shows that Indian states have contained their public investment spending to comply with a fiscal rule once the regression has controlled for the growth of intergovernmental transfers and other statespecific factors. However, most states have overadjusted their fiscal deficit, resulting in the accumulation of cash surpluses. The impact of the decline in investment spending on growth is an area for further research.

To conclude, this phenomenon of accumulation of a cash surplus under a rule-based fiscal regime at the subnational level was addressed by the 14th Finance Commission by changing the design of the fiscal rules. The 14th Finance Commission has proposed that for the Union government, the fiscal deficit ceiling will be 3 percent of GDP from fiscal year 2016-17 onwards. However for the states, there is flexibility for 0.25 percent over and above 3 percent of GSDP for a given year if the debt-to-GSDP ratio is below 25 percent. Also if the states limit their interest obligations as a percentage of revenue receipts below 10 percent, an additional 0.25 percent of GSDP is allowed as extra fiscal space for capital spending. States will be eligible for these flexibilities in borrowing only if there is no revenue deficit. One needs to see how much the 14th Finance Commission's recommendations are going to change state-level fiscal behavior and the utilization of borrowed resources for capital spending within the existing federal fiscal framework of transfers. 


\section{APPENDIX}

Table A1: Instruments and Nature of Fiscal Rule: A Cross Country Comparison

\begin{tabular}{|c|c|c|c|c|}
\hline Country & Year & $\begin{array}{l}\text { Name and Nature of } \\
\text { Act }\end{array}$ & $\begin{array}{l}\text { Numerical } \\
\text { Targets }\end{array}$ & Description \\
\hline USA & $\begin{array}{l}1990 \\
2010\end{array}$ & $\begin{array}{l}\text { Gramm-Rudman- } \\
\text { Hollings Act (GRH) } \\
\text { Budget Enforcement Act } \\
\text { - Expenditure rule } \\
\text { Pay-As-You-Go } \\
\text { (PAYGO) Act } \\
\\
\text { Balanced Budget Rule - } \\
\text { Expenditure based }\end{array}$ & $\begin{array}{l}\text { Yes } \\
\text { No }\end{array}$ & $\begin{array}{l}\text { Specified a series of annual deficits targets with } \\
\text { a balanced budget to be achieved in } 1991 \text { and } \\
\text { subsequently moved to } 1993 \text {. } \\
\text { Annual appropriations limit adopted for } \\
\text { discretionary spending. } \\
\text { Deficit-raising policies must be financed by } \\
\text { other measures over a specified time period. } \\
\text { Exempt programs included legislation with an } \\
\text { "emergency” designation, Social Security, and } \\
\text { the Bush tax cuts for the middle class. } \\
\text { Discretionary spending caps were introduced. } \\
\text { Additional spending cuts came into effect in } \\
\text { March } 2013 \text {. These additional cuts are expected } \\
\text { to reduce US\$1.2 trillion over a decade with } \\
\text { one-half coming from defense spending and the } \\
\text { other half from domestic programs, excluding } \\
\text { Social Security, Medicaid, parts of Medicare, } \\
\text { and certain other entitlement programs. }\end{array}$ \\
\hline Japan & $\begin{array}{l}1947 \\
1997 \\
2006 \\
2010\end{array}$ & $\begin{array}{l}\text { Balanced Budget Rule } \\
\text { Fiscal Structure Reform } \\
\text { Act } \\
\text { Expenditure Rule } \\
\text { Fiscal Management } \\
\text { Strategy }\end{array}$ & $\begin{array}{l}\text { No } \\
\text { Yes } \\
\text { Yes } \\
\text { No }\end{array}$ & $\begin{array}{l}\text { Current expenditure should not exceed } \\
\text { domestic revenues. } \\
\text { Revised balance budget rule: Reduce overall } \\
\text { government deficit to } 3 \text { percent of GDP; } \\
\text { numerical targets by spending category (public } \\
\text { investment, Social Security). } \\
\text { Any major increases in expenditure or } \\
\text { decreases in revenue need to be accompanied } \\
\text { by permanent expenditure reductions/revenue- } \\
\text { raising measures. }\end{array}$ \\
\hline Canada & $\begin{array}{l}1991 \\
1998 \\
2006\end{array}$ & $\begin{array}{l}\text { Federal Spending } \\
\text { Control Act } \\
\text { Debt Repayment Plan } \\
\text { Target-based Plans }\end{array}$ & $\begin{array}{l}\text { Yes } \\
\text { No } \\
\text { No }\end{array}$ & $\begin{array}{l}\text { C\$3 billion debt reduction and limitation in } \\
\text { program spending except self-financing } \\
\text { programs. } \\
\text { Eliminating net general government debt by } \\
2021 \text { and federal debt by } 2013 / 14\end{array}$ \\
\hline EU & $\begin{array}{l}1992 \\
2005 \\
2012\end{array}$ & $\begin{array}{l}\text { Maastricht Treaty } \\
\text { Stability and Growth } \\
\text { Pact } \\
\text { Golden Rule }\end{array}$ & $\begin{array}{l}\text { Yes } \\
\text { No } \\
\text { Yes }\end{array}$ & $\begin{array}{l}\text { Debt and deficit ceiling: } 60 \text { and } 3 \text { percent of } \\
\text { GDP, respectively. } \\
\text { Country-specific medium-term objectives are } \\
\text { set for structural budget balance. } \\
\text { Annual pace of debt reduction (no less than } \\
1 / 20 \text { th of the distance between the actual debt } \\
\text { ratio and the } 60 \text { percent threshold) starting } \\
\text { three years after a country has left the current } \\
\text { excessive debt procedure (EDP). }\end{array}$ \\
\hline
\end{tabular}




\begin{tabular}{|c|c|c|c|c|}
\hline Argentina & 2004 & $\begin{array}{l}\text { Fiscal Responsibility } \\
\text { Law (FRL) } \\
\text { Implementation of } \\
\text { Revised FRL }\end{array}$ & Yes & $\begin{array}{l}\text { Balanced budget rule: Balance revenue and } \\
\text { expenditure excluding social and infrastructure } \\
\text { expenditure. Additionally, for provinces debt- } \\
\text { servicing costs cannot exceed } 15 \text { percent of } \\
\text { current revenues after transfers deduction. } \\
\text { Expenditure rule: Primary expenditure cannot } \\
\text { grow more than nominal GDP; Federal Fiscal } \\
\text { Responsibility Council was instated in 2000, } \\
\text { however its activities were suspended in 2009. }\end{array}$ \\
\hline \multirow[t]{3}{*}{ Peru } & 2000 & Balanced Budget Rule & Yes & $\begin{array}{l}\text { Deficit ceiling for the non-financial public } \\
\text { sector. The ceiling was set at } 2 \text { percent of GDP } \\
\text { for } 2000 \text { and 2003, } 1.5 \text { percent of GDP for } \\
\text { 2001, } 2002 \text {, and from } 2004-2008 \text {. Real growth } \\
\text { current expenditure ceiling of } 2 \text { percent (2000- } \\
02 \text { ), } 3 \text { percent (2003-08). }\end{array}$ \\
\hline & 2009 & Balanced Budget Rule & Yes & $\begin{array}{l}\text { New limit of } 2 \text { percent for balanced budget was } \\
\text { set. Real growth of current expenditure limit } \\
\text { was at } 4 \text { percent, structural deficit limit at } 1 \\
\text { percent of GDP. }\end{array}$ \\
\hline & 2013 & Law 30099 & No & $\begin{array}{l}\text { Expenditure on maintenance of infrastructure, } \\
\text { goods, and services of social programs covered } \\
\text { by the performance-based budgeting scheme; } \\
\text { equipment intended for public order and } \\
\text { security were excluded from current } \\
\text { expenditure and were out of the ambit of the } \\
\text { stipulated limits. }\end{array}$ \\
\hline \multirow[t]{3}{*}{ Mexico } & 2006 & $\begin{array}{l}\text { Balanced Budget Rule - } \\
\text { Cash basis }\end{array}$ & No & $\begin{array}{l}\text { Rule applies to the federal public sector which } \\
\text { includes the central government, social } \\
\text { security, and key public enterprises. }\end{array}$ \\
\hline & 2009 & Balanced Budget Rule & Yes & $\begin{array}{l}\text { Status quo with exclusion of investment outlays } \\
\text { of the state-owned oil company, Pemex, from } \\
\text { the balanced-budget rule. Although sanctions } \\
\text { were also thought of, escape clauses also } \\
\text { existed. }\end{array}$ \\
\hline & 2013 & Expenditure Rule & Yes & $\begin{array}{l}\text { Cap on structural current spending (SCS) } \\
\text { defined as current primary expenditure } \\
\text { including transfers to state and local } \\
\text { governments for capital but excluding those } \\
\text { outlays governed by automatic rules (pensions, } \\
\text { subsidies for electricity, and tax devolution); } \\
\text { SCS cannot grow faster than } 2 \text { percent in real } \\
\text { terms through } 2017 \text {. }\end{array}$ \\
\hline \multirow[t]{2}{*}{ Australia } & 1985 & Expenditure Rule & Yes & $\begin{array}{l}\text { Expenditure Rule, Balanced Budget Rule, } \\
\text { Revenue Rule }\end{array}$ \\
\hline & 1998 & $\begin{array}{l}\text { Charter of Budget } \\
\text { Honesty Act }\end{array}$ & Yes & $\begin{array}{l}\text { Achieve budget surpluses over the medium } \\
\text { term; keep taxation as a share of GDP below } \\
\text { the level of 2007-08. Improve the } \\
\text { government's net financial worth over the } \\
\text { medium term. Commitment to restrain real } \\
\text { growth in spending to } 2 \text { percent per year since } \\
2009 \text {. }\end{array}$ \\
\hline Brazil & 2000 & $\begin{array}{l}\text { Fiscal Responsibility } \\
\text { Law }\end{array}$ & Yes & $\begin{array}{l}\text { Expenditure rule: Personnel expenditure is } \\
\text { limited to } 50 \text { percent of net current revenue for } \\
\text { the federal government, and } 60 \text { percent for } \\
\text { states and municipalities. } \\
\text { Debt rule: New borrowing must be at most } \\
\text { equal to public investment. }\end{array}$ \\
\hline
\end{tabular}




\begin{tabular}{|c|c|c|c|c|}
\hline Cameroon & $\begin{array}{l}2002 \\
2008\end{array}$ & $\begin{array}{l}\text { Balanced Budget Rule } \\
\text { Revised Balanced } \\
\text { Budget Rule }\end{array}$ & $\begin{array}{l}\text { No } \\
\text { No }\end{array}$ & $\begin{array}{l}\text { The Central African Economic and Monetary } \\
\text { Community (CEMAC) sets the fiscal rule. } \\
\text { Structural fiscal balance and non-oil basic fiscal } \\
\text { balance, respectively, as a percentage of } \\
\text { nominal GDP should be in balance/surplus. }\end{array}$ \\
\hline Indonesia & $\begin{array}{l}1967 \\
2004\end{array}$ & $\begin{array}{l}\text { Balance Budget Rule } \\
\text { Debt Rule }\end{array}$ & $\begin{array}{l}\text { Yes } \\
\text { Yes }\end{array}$ & $\begin{array}{l}\text { The consolidated national and local } \\
\text { government budget deficit is limited to } 3 \\
\text { percent of GDP in any given year as per State } \\
\text { Finance Law and Government Regulation } \\
\text { 23/2003. } \\
\text { Central and local government debt should not } \\
\text { exceed } 60 \text { percent of GDP. }\end{array}$ \\
\hline India & $\begin{array}{l}2004 \\
2009\end{array}$ & $\begin{array}{l}\text { Budget Balance Rule } \\
\text { Revised Budget Balance } \\
\text { Rule }\end{array}$ & $\begin{array}{l}\text { Yes } \\
\text { No }\end{array}$ & $\begin{array}{l}\text { Fiscal Responsibility and Budget Management } \\
\text { Act (FRBMA): reduce the fiscal deficit to } 3 \\
\text { percent of GDP by } 2008 . \\
\text { FRBMA was suspended in 2009. All states } \\
\text { barring three had met the targets; however, the } \\
\text { central government had not achieved the } \\
\text { stipulated targets. }\end{array}$ \\
\hline Kenya & 1997 & Debt-based Rule & Yes & $\begin{array}{l}\text { The debt-to-GDP ratio in net present value } \\
\text { terms should be below } 40 \text { percent and/or total } \\
\text { nominal debt to be below } 45 \text { percent of GDP (a } \\
\text { goal of their medium-term debt-management } \\
\text { strategy); government overdraft at the central } \\
\text { bank is limited to } 5 \text { percent of previous year } \\
\text { revenue; revenue should be at } 21-22 \text { percent of } \\
\text { GDP. }\end{array}$ \\
\hline $\begin{array}{l}\text { New } \\
\text { Zealand }\end{array}$ & 1994 & $\begin{array}{l}\text { Fiscal Responsibility } \\
\text { Act }\end{array}$ & & $\begin{array}{l}\text { The government needs to run operating } \\
\text { surpluses annually until "prudent” debt levels } \\
\text { are achieved. Once these are achieved on } \\
\text { average total operating balances should not } \\
\text { exceed total operating revenues. In case of } \\
\text { deviations from the principles, the government } \\
\text { needs to specify the reasons; specific fiscal } \\
\text { targets should be set by the government for } \\
\text { three-year and ten-year objectives, typically in } \\
\text { percent of GDP. }\end{array}$ \\
\hline Russia & 2012 & $\begin{array}{l}\text { Balanced Budget Rule } \\
\text { Oil-price-based Fiscal } \\
\text { Rule }\end{array}$ & & $\begin{array}{l}\text { Russia's legal fiscal framework relied on the } \\
\text { non-oil balance as a key fiscal indicator. The } \\
\text { budget included a long-term non-oil deficit } \\
\text { target of } 4.7 \text { percent of GDP. This was } \\
\text { suspended in April } 2009 \text { as a result of the } \\
\text { global financial crisis, and formally abolished } \\
\text { in } 2012 \text {. } \\
\text { The rule sets a ceiling on expenditures (oil } \\
\text { revenue at the "base" oil price, plus all non-oil } \\
\text { revenues, plus a net borrowing limit of } 1 \\
\text { percent of GDP). Once the reserve fund reaches } \\
\text { this threshold, at least half of excess oil } \\
\text { revenues should go to the National Wealth } \\
\text { Fund, while the remaining resources would be } \\
\text { channeled to the budget to finance } \\
\text { infrastructure and other priority projects. }\end{array}$ \\
\hline
\end{tabular}




\begin{tabular}{|c|c|c|c|}
\hline Singapore & $\begin{array}{l} \\
1995 \\
2008\end{array}$ & $\begin{array}{l}\text { Debt Rule } \\
\text { Balanced Budget Rule } \\
\text { (BBR) } \\
\text { Amendment to BBR }\end{array}$ & $\begin{array}{l}\text { Spending to not exceed } 50 \text { percent of net } \\
\text { investment returns on reserves held by the } \\
\text { Monetary Authority of Singapore (MAS) and } \\
\text { the Government of Singapore Investment } \\
\text { Corporation (GIC). } \\
\text { Budget to be balanced across government term } \\
\text { of office (usually } 5 \text { years). } \\
\text { The rule was amended in } 2008 \text { to change the } \\
\text { benchmark to "expected long-term net real } \\
\text { investment returns." }\end{array}$ \\
\hline
\end{tabular}


Table A2: Date of FRBMA and Period for Calculating Average

\begin{tabular}{|c|c|c|c|c|}
\hline Sl. No & State & $\begin{array}{c}\text { Month of } \\
\text { FRBM }\end{array}$ & Period before FRBM & Period after FRBM \\
\hline 1 & Karnataka & Sep 2002 & $1992-93$ to 2001-02 & $2003-04$ to $2012-13$ \\
\hline 2 & Tamil Nadu & May 2003 & $1994-95$ to $2002-03$ & $2004-05$ to $2012-13$ \\
\hline 3 & Kerala & Aug 2003 & $1994-95$ to $2002-03$ & $2004-05$ to $2012-13$ \\
\hline 4 & Punjab & Oct 2003 & $1994-95$ to $2002-03$ & $2004-05$ to $2012-13$ \\
\hline 5 & Uttar Pradesh & Feb 2004 & $1994-95$ to 2002-03 & $2004-05$ to $2012-13$ \\
\hline 6 & Gujarat & Mar 2005 & $1998-99$ to $2004-05$ & $2006-07$ to $2012-13$ \\
\hline 7 & Mahrashtra & Apr 2005 & 1998-99 to 2004-05 & $2006-07$ to $2012-13$ \\
\hline 8 & Himachal Pradesh & Apr 2005 & 1998-99 to 2004-05 & $2006-07$ to $2012-13$ \\
\hline 9 & Rajasthan & May 2005 & 1998-99 to 2004-05 & $2006-07$ to $2012-13$ \\
\hline 10 & Madhya Pradesh & May 2005 & $1998-99$ to $2004-05$ & $2006-07$ to $2012-13$ \\
\hline 11 & Andhra Pradesh & Jun 2005 & $1998-99$ to $2004-05$ & $2006-07$ to $2012-13$ \\
\hline 12 & Odisha & Jun 2005 & $1998-99$ to $2004-05$ & $2006-07$ to $2012-13$ \\
\hline 13 & Tripura & Jun 2005 & 1998-99 to 2004-05 & $2006-07$ to $2012-13$ \\
\hline 14 & Haryana & Jul 2005 & $1998-99$ to $2004-05$ & $2006-07$ to $2012-13$ \\
\hline 15 & Manipur & Aug 2005 & $1998-99$ to $2004-05$ & $2006-07$ to $2012-13$ \\
\hline 16 & Chhattishgarh & Sep 2005 & $2000-01$ to $2004-05$ & $2006-07$ to $2012-13$ \\
\hline 17 & Assam & Sep 2005 & $1998-99$ to $2004-05$ & $2006-07$ to $2012-13$ \\
\hline 18 & Uttarakhand & Oct 2005 & $1998-99$ to $2004-05$ & $2006-07$ to $2012-13$ \\
\hline 19 & Arunanchal Pradesh & Mar 2006 & $1998-99$ to $2004-05$ & $2006-07$ to $2012-13$ \\
\hline 20 & Meghalaya & Mar 2006 & $1998-99$ to $2004-05$ & $2006-07$ to $2012-13$ \\
\hline 21 & Bihar & Apr 2006 & $2001-02$ to $2005-06$ & $2007-08$ to $2012-13$ \\
\hline 22 & Goa & May 2006 & $2001-02$ to $2005-06$ & $2007-08$ to $2012-13$ \\
\hline 23 & Jammu and Kashmir & Aug 2006 & $2001-02$ to $2005-06$ & $2007-08$ to $2012-13$ \\
\hline 24 & Mizoram & Oct 2006 & $2001-02$ to $2005-06$ & $2007-08$ to $2012-13$ \\
\hline 25 & Jharkhand & May 2007 & $2002-03$ to $2006-07$ & $2008-09$ to $2012-13$ \\
\hline 26 & Nagaland & Jan 2010 & $2006-07$ to $2008-09$ & $2010-11$ to $2012-13$ \\
\hline 27 & West Bengal & Jul 2010 & $2008-09$ to $2009-10$ & $2011-12$ to $2012-13$ \\
\hline 28 & Sikkim & Sep 2010 & $2008-09$ to $2009-10$ & $2011-12$ to $2012-13$ \\
\hline
\end{tabular}

Source: Reserve Bank of India Study on State Finances, 2014-15 


\section{REFERENCES}

Alesina, A., and T. Bayoumi. 1996. "The costs and benefits of fiscal rules: evidence from US states.” NBER Working Paper No. 5614. Cambridge, MA: National Bureau of Economic Research.

Alt, J.E., and R.C. Lowry. 1994. "Divided Government, Fiscal Institutions, and Budget Deficits: Evidence from the States.” American Political Science Review 88(04): 81128.

Bertelsmann, J.I. 2013. "Independent Fiscal Institutions in the Face of Rising Public Indebtedness.” In George Kopits (ed.), Restoring Public Debt Sustainability: The Role of Independent Fiscal Institutions. Oxford: Oxford University Press.

Buchanan, J.M., and R.E. Wagner. 1977. Democracy in deficit: the political legacy of Lord Keynes. New York: Academic Press.

Chakraborty, P., and B.B. Dash. 2013. "Fiscal Reforms, Fiscal Rule and Development Spending: How Indian States have performed?” National Institute of Public Finance and Policy Working Paper 2013-122. New Delhi: National Institute of Public Finance and Policy.

Feld, L.P., and G. Kirchgässner. 2006. "Fiscal Policy and Direct Democracy: Institutional Design Determines Outcomes.” In A.F. Ott and R.J. Cebula (eds.) The Elgar Companion to Public Economics: Empirical Public Economics. Cheltenham: Edward Elgar.

Finance Commission. 2004. "Report of the Twelfth Finance Commission.” New Delhi: Finance Commission.

Finance Commission. 2009. "Report of the Thirteenth Finance Commission” New Delhi: Finance Commission.

Finance Commission. 2014. "Report of the Fourteenth Finance Commission” New Delhi: Finance Commission.

Gupta, S., B. Clemens, A. Pivovarsky, and E.R. Tiongson. 2003. "Foreign Aid and Revenue Response: Does the Composition of Aid Matter?” IMF Working Paper 03/176, September. Washington, DC: International Monetary Fund.

Hatchondo, J.C., L. Martinez, and F. Roch. 2012. "Fiscal rules and the sovereign default premium.” IMF Working Paper 12/130. Washington, DC: International Monetary Fund.

Khemani, S., and W. Wane. 2008. "Populist Fiscal Policy.” World Bank Policy Research Working Paper, 4762. Washington, DC: World Bank.

Kopits, G. 2013. Restoring public debt sustainability: the role of independent fiscal institutions. Oxford: Oxford University Press. 
Kopits, G. 2001. “Fiscal rules: Useful Policy Framework or Unnecessary Ornament?” IMF Working Paper, WP/1/145. Washington, DC: International Monetary Fund.

Kopits, G., and S.A. Symansky. 1998. “Fiscal Policy Rules.” IMF Occasional Paper 162. Washington, DC: International Monetary Fund.

Krogstrup, S., and S. Wälti. 2008. “Do fiscal rules cause budgetary outcomes?” Public Choice 136(1-2): 123-38.

Kydland, F. E., and E.C. Prescott. 1977. "Rules rather than discretion: The inconsistency of optimal plans.” The Journal of Political Economy 85(3): 473-91.

Manasse, P. 2007. “Deficit limits and fiscal rules for dummies.” IMF Staff Papers 455-473. Washington, DC: International Monetary Fund.

Mavrotas, G., and B. Ouattara. 2003. “Aid Disaggregation, Endogenous Aid, and the Public Sector in Aid-Recipient Economies: Evidence from Cote d'Ivoire.” Working Paper Series UNU-WIDER Research Paper. Helsinki: World Institute for Development Economic Research (UNU-WIDER).

Milesi-Ferretti, G.M., and K. Moriyama. 2004. "Fiscal adjustment in EU countries: a balance sheet approach.” IMF Working Paper, WP/04/143. Washington, DC: International Monetary Fund

Pappa, E., and V. Vassilatos. 2007. "The unbearable tightness of being in a monetary union: Fiscal restrictions and regional stability.” European Economic Review 51(6): 14921513.

Poplawski Ribeiro, M., R. Beetsma, and A. Schabert. 2008. "A Comparison of Debt and Primary-deficit Constraints.” CEPR Discussion Paper No. 6897. Washington, DC: Center for Economic and Policy Research.

Poterba, J.M. 1995. "Balanced budget rules and fiscal policy: Evidence from the states.” National Tax Journal 48(3): 329-36.

Rao, M.G., and P. Chakraborty. 2007, "Multilateral adjustment lending to states in India: Hastening fiscal correction or softening the budget constraint?" The Journal of International Trade and Economic Development 3(15): 335-57.

Schaltegger, C.A. 2001. "The Effects of Federalism and Democracy: Evidence from Swiss Subnational Jurisdictions.” ifo-Studien 47: 145-62.

Simone, A.S., and P. Topalova. 2009, “India’s Experience with Fiscal Rules: An Evaluation and The Way Forward.” IMF Working Paper 09/175. Washington, DC: International Monetary Fund.

Spaventa, L. 1987. "The growth of public debt: sustainability, fiscal rules, and monetary rules.” IMF Staff Papers 374-399. Washington, DC: International Monetary Fund. 
Tellier, G., and L.M. Imbeau. 2004. "Budget deficits and surpluses in the Canadian provinces: a pooled analysis.” Paper presented at the annual conference of the European Public Choice Society, Berlin. Available at: http://www.diw.de/documents/dokumentenarchiv/17/41570/paper-246.pdf

Von Hagen, J., and I. Harden. 1996. "Budget processes and commitment to fiscal discipline.” IMF Working Paper WP/96/78. Washington, DC: International Monetary Fund.

World Bank. 2004. "State Fiscal Reforms in India: Progress and Prospects.” A World Bank Report, No. 28849-IN. New Delhi: Macmillan India, Ltd.

World Bank. 1992. “Adjustment Lending and Mobilization of Public and Private Resources for Growth.” World Bank Policy and Research Series 22. Washington, DC: World Bank. 